\title{
IMPROVING STUDENTS' LISTENING ABILITY BY USING CHAIN WHISPERING WORDS OR SENTENCES TECHNIQUE AT THE FIRST YEAR OF SMP SOMBA OPU SUNGGUMINASA GOWA
}

\author{
Mukarrama, $\mathbf{H j}$. Mardianah, H. Abd. Muis Said \\ English Education Department of UIN Alauddin Makassar \\ Mukarramaamma@yahoo.com
}

\begin{abstract}
This thesis aimed at finding out the student's increase ability in listening by using Chain Whispering Technique and the students' attitude toward the use of the technique. The problem statement in this research are:(1) what is the students improvement their abilities in listening by using Chain Whisper Technique? (2) What is the students' attitude toward the use of Chain Whisper technique?. The researcher used pre experimental method with one group pre-test and post test design. The population was 60 students at the first year of SMP Somba Opu Sungguminasa Gowa in academic 2013/2014. The number of sample was 30 students. The instrument of this research consisted of two kinds' namely listening test (pre-test and post-test) and questionnaire for students' attitude. The mean score of the students pre-test was 6.56 and the means score of the students post-test 7.23. T-test value (6.696) was greater than $\mathrm{T}$-table value (2.045). It means that chain whispering technique can increase the students' ability listening because there is significance between pre-test and post-test increase before and after used chain whisper technique and questionnaire show that the students gave positive attitude toward. There are the importance of chain whispering technique as follow: To improve the students ability in listening skill, to measure the students ability directly in listening, to improve the students ability pronounce English word, this technique is easy to apply. (Ice Sutari, Tiem Kartini, Vismaia, (1997:143-144).
\end{abstract}

\section{KEY WORDS:}

\section{A. INTRODUCTION}

$\mathbf{I}$ $\mathrm{n}$ the process of teaching and learning English, there are four skills in English as the second or foreign language, namely; Listening, reading, speaking and writing. Listening skill (understanding the spoken language), reading skill (understanding written language) and productive skills, speaking skill (producing spoken language) and writing skill (producing written language).The writer emphasized in the listening skill, because listening as receptive skill, more important 
to the develop the students competence and performance in language. Listening is an essential competence of English. We always want to know what other people say and hear. Listening is not giving passive attention to what is said but more than that we have to be active to get the meaning of the language.

Listening is very important in language learning, students understand the content of spoken language by listening. The relationship between listening and language learning is that language learning depends on listening. Listening provides the aural input that serves as the basis for language acquisition and enables learners to interact in spoken language.

Considering important of listening skill in day communication, English learners should work hard improve their listening ability, they have to practice listening to speech language. English teachers are demand to be more creative

to present their lesson they must have some technique when they give the material to students.

Silberman(1998:1) state that "what I hear, I forget; what I hear and see, I remember a little; what I hear, see, and ask question about or discuss whit someone else, I begin to understand; what I hear, see, discuss, and do I acquire knowledge and skill; what I teach to another, I master".

Most of teacher would agree that listening comprehension is one of the most of important and perhaps the most difficult skill to teach to the students of English country where English is foreign language.

Relating to teacher's way to improve their students in listening which is considered as a difficult subject which should be taught in various ways to make students stimulated and to be more creative to learn it, the writer proposed one method in teaching listening by Using Chain whisper technique.

Based on the explanation above, the researcher tried to conducted her research under the title: 'Improving students' listening Ability by Using Chain Whispering Words or Sentences Technique at the first year students of SMP Somba Opu Sungguminasa Gowa"

\section{B. LITERATURE REVIEW}

Some previous researchers that also support the idea of this research as follow:

1. Faridah, Kartono, Siti Halidjah(2012)"The Use Chain Whisper technique to Improve Ability Listening skill. Stated that on observation listening skills using game chain whisper technique was successful. It is evident from the increase 
Mukarrama dkk, Improving students' Listening Ability by Using Chain Whispering Words ...

listening skill which has increased from the first cycle to the meeting 1 and 2 and cycle 2 meeting to1 and 2 .

2. Apriani Sufiarti, A.A.I.N. Marhaeni, I.M. Sutama (2013) "The influence using chain whisper technique on listening skills and learning interests of students". Stated that results of the research show that English listening skills and learning interests of students who take lessons using chain whisper technique is higher than the group of students who take conventional learning. These results also demonstrate that using chain whisper techniques in learning English can improve listening skill and students' interest in learning English.

3. Kurnia Zulianti PBI FKIP Unisma (2013)"Improving Speaking Achievement using chain whisper game". Stated that implementation of whispering game have positive result and can be concluded that the improving students' speaking achievement of second grade at SMKN 01 Batu by using whisper game increased students' speaking achievement. It was signed that $70 \%$ students' participation active.

4. It means that teaching English speaking skill by using whisper game was successful, Finally, this technique implied that it could be used by the teacher for speaking class to develop and improve the students' speaking achievement with any other activity and style based on the students' interest. By using whisper game, teaching speaking was succeeding.

Referring to some previous research findings, the researcher concluded that the students' listening ability can be improved after giving some interesting techniques or more exercises or using unusual media. It means that English teachers should have a variety of techniques in order to avoid of being bored of students. It is therefore, she is sure that this technique, chain whisper technique might be beneficial for them to increase their listening

\section{RESEARCH METHOD}

The method applied in this research was pre-experimental method with one group pre-test and post-test. To know the student's listening ability by using "Chain Whisper Technique". The design formulated as follows:

\begin{tabular}{|c|c|c|}
\hline Pre-test & Treatment & Post-test \\
\hline O1 & $\mathrm{X}$ & O2 \\
\hline
\end{tabular}

Notations:

$$
\text { Pre-test }=\mathbf{O} 1
$$


Volume I, Number 02, December 2015

$$
\begin{array}{ll}
\text { Treatment } & =\mathbf{X} \\
\text { Post-test } & =\mathbf{O} 2
\end{array}
$$

(Gay, 1981: 225)

\section{Research Variables}

a. Independent variable (IV) : Teaching Listening through Chain Whisper technique

b. Dependent variable (DV) : Students Achievement in Listening.

\section{Population and Sample}

a. Population

Population is the overall research subject (Arikunto:2006). The population that the researcher used was all the first year of SMP Somba Opu Sungguminasa Gowa in academic year 2013/2014. The are two clasees each class consist of 30 students, so the total population is 60 students.

b. Sample

Sample is a part of the population which as a representative (Arikunto: 2006). Here, the researcher used purposive sampling technique. The researcher choose one class, namely class $1 . \mathrm{A}$, so the total sample is 30 students.

\section{Instrument of the Research}

There were two kind of instrument applied in this research, namely:

a. Listening test.

The listening test used of two parts namely pretest and posttest. The pre test was given before the treatment and the post-test was after the treatment to find out the students' ability in listening comprehension.

b. Questionnaire

The questionnaire is to find out the students' attitude toward the use of chain whisper Technique in teaching listening. This instrument consisted of ten items. The Student is expected to give their response toward the statements in the questionnaire.

\section{Procedure of Data Collection}

In collecting data, the writer used the following procedures as follows:

\section{a. Pre-test}

The researcher gave the pretest which consisted of 2 item. The researcher read text for three times and asked the students to choose the right answer the question. It is apply by one meeting.

b. Treatment

After giving pretest the researcher introduction and apply strategy by giving treatment. The treatment is applied by three meetings. 
Mukarrama dkk, Improving students' Listening Ability by Using Chain Whispering Words ...

1) First Meeting

For the first meeting the researcher introduce and explain about Chain Whisper Technique.

2) Second Meeting

For the second meeting the researcher give treatment test with the topic "what is your Sport" and then the students listen the sentence which is Whisper by teacher.

3) Third Meeting

For the third meeting, the students whispered the sentence to the other by chain whisper in every group. It is apply by 60 minutes. And every group reconfirm or conveying the sentence which is listened. It is applied by 25 minutes.

\section{c. Pos-test}

The researcher gave test which same as pre-test and ask them to listen the text and choose the right answer. The researcher just read the text for two times. It is apply by one meeting.

\section{Technique of Data Analysis}

The data have been collected in line with instruments and was analyzed by using the following procedures:

a. Calculating the mean score by applying the formula:

$$
\mathrm{X}=\frac{2 \mathrm{X}}{\mathrm{N}}
$$

$$
\text { Which } \quad \begin{aligned}
X & =\text { Mean } \\
X & =\text { The Sum of all scores } \\
\mathrm{N} & =\text { The total number of sample }
\end{aligned}
$$

b. Finding the mean score of difference score using the following formula:

$$
\begin{aligned}
M d & =\frac{2 D}{N} \\
\text { Which } M d & =\text { Mean differences score } \\
\Sigma D & =\text { The sum of all score } \\
\mathrm{N} & =\text { Total number of sample }
\end{aligned}
$$

(Arikunto, 2013:350)

c. Finding out students' deviation by using formula:

$$
\begin{aligned}
\Sigma X \mathrm{~d} 2 & =\square \mathrm{d}^{2}-(\square \mathrm{d})^{2} \\
& \mathrm{~N} \\
\text { Which } \Sigma \mathrm{X} d 2 & =\text { Standard deviation }
\end{aligned}
$$


Volume I, Number 02, December 2015

$$
\begin{aligned}
\Sigma d 2 & =\text { The sum of all score } \\
\mathrm{N} & =\text { Total of sample }
\end{aligned}
$$

(Arikunto, 2013: 351)

d. Finding out the significant difference between pre-test and post-test value of the t- test using the following formula:

$$
\begin{aligned}
t=\frac{M d}{\sqrt{\frac{\sum X^{2}}{N(N-1)}}} & \\
\text { Where } \mathrm{t} & =\text { Test of significance } \\
M d & =\text { Mean differences score } \\
\mathrm{X}^{2} \mathrm{~d} & =\text { The sum of all score } \\
\mathrm{N} & =\text { Total number of sample }
\end{aligned}
$$

(Arikunto, 2013:350)

e. Classifying the students' scores using the following scales:

\begin{tabular}{|c|l|c|}
\hline NO & Classification & Score \\
\hline 1. & Excellent & $9.5-10$ \\
2. & Very Good & $8.5-9$ \\
3. & Good & $7.5-8$ \\
4. & Fairly good & $6.5-7$ \\
5. & Fair & $5.5-6$ \\
6. & Poor & $4.5-5$ \\
7. & Very Poor & $0-4$ \\
\hline
\end{tabular}

(Dik Bud, 1985:17)

f. Calculating the percentage of the students' score:

$$
\begin{array}{ll}
\mathrm{P}=\frac{\mathrm{F}}{\mathrm{N}} \times 100 \% \\
\mathrm{P}=\text { Percentage } \\
\mathrm{F}=\text { Frequency } \\
\mathrm{N}=\text { the total number of students }
\end{array}
$$

(La passa cited in Nur Zamzam 2007:8)

\section{D.FINDINGS}

This chapter deals with the presentation of data analysis as well as the discussion of the research. The instrument of this research is test of listening comprehension as put in previous chapter namely objective test consisting of pretest, post-test and questionnaire. Those data were analyzed to describe the students' 
Mukarrama dkk, Improving students' Listening Ability by Using Chain Whispering Words ...

comprehension of listening ability and also the students' attitude in teaching listening by using Chain Whisper Technique.

The result of data analysis that there was improvement of the students' listening ability by using chain whisper technique in teaching listening. The prior score pre-test was quite different from the post test as in the following table:

1. The Rate Percentage and frequency of the Listening score on pre-test

\begin{tabular}{|c|l|c|c|c|}
\hline \multirow{2}{*}{ No. } & \multirow{2}{*}{ Classification } & \multirow{2}{*}{ Score } & \multicolumn{2}{|c|}{ Pre Test } \\
\cline { 4 - 5 } & & & Frequency (F) & Percentage (\%) \\
\hline 1. & Excellent & $9,5-10$ & - & - \\
\hline 2. & Very good & $8,5-9$ & - & - \\
\hline 3. & Good & $7,5-8$ & 8 & $26.6 \%$ \\
\hline 4. & Fairly good & $6,5-7$ & 9 & $30 \%$ \\
\hline 5. & Fair & $5,5-6$ & 10 & $33.4 \%$ \\
\hline 6. & Poor & $4,5-5$ & 1 & $3.4 \%$ \\
\hline 7. & Very poor & $0-4$ & 2 & $6.6 \%$ \\
\hline & TOTAL & & 30 & $100 \%$ \\
\hline
\end{tabular}

The table above shows that before using Chain Whisper Technique there were $10(33.4 \%)$ of 30 students get fair score.

2. The Rate percentage and frequency of the listening score on post -test

\begin{tabular}{|c|l|c|c|c|}
\hline \multirow{2}{*}{ No. } & \multirow{2}{*}{ Classification } & \multirow{2}{*}{ Score } & \multicolumn{2}{|c|}{ Pos- Test } \\
\cline { 4 - 5 } & & & Frequency (F) & Percentage (\%) \\
\hline 1. & Excellent & $9,5-10$ & - & - \\
\hline 2. & Very good & $8,5-9$ & 3 & $10 \%$ \\
\hline 3. & Good & $7,5-8$ & 9 & $30 \%$ \\
\hline 4. & Fairly good & $6,5-7$ & 15 & $50 \%$ \\
\hline 5. & Fair & $5,5-6$ & 3 & $10 \%$ \\
\hline 6. & Poor & $4,5-5$ & - & - \\
\hline 7. & Very poor & $0-4$ & - & - \\
\hline \multicolumn{2}{|l|}{ TOTAL } & 30 & $100 \%$ \\
\hline
\end{tabular}

The table above shows that after using Chain Whisper Technique in teaching Listening there were $3(10 \%)$ of 30 students got fair score.

The data shows that their listening ability is proved there is a significant difference between the mean score of the students' pre-test and post-test was applied. 


\section{The mean Score of pre-test and post-test}

The result of the students pre-test and post-test, after calculating the mean score are presented in the following table:

\begin{tabular}{|l|l|}
\hline Type of Test & Means score \\
\hline Pre - test & 6.56 \\
\hline Post - test & 7.23 \\
\hline
\end{tabular}

The table above shows that the mean score of the students pre-test 6.56 and the mean score of the students post-test 7.23. The mean score of post-test will be higher than the mean score of pre-test. It means that using Chain Whispering Technique is effective to improving the students' Listening ability.

4. Test Significance

\begin{tabular}{|c|c|c|}
\hline Variabel & T- test & T- table \\
\hline X2-X1 & 6.696 & 2.045 \\
\hline
\end{tabular}

The Table above showed that $\mathrm{T}$ - test value (6.696) will be higher than $\mathrm{T}$ table value (2.045) of the students' listening ability.

The result of the statistical analysis for the level of significance $(p)=0.05$ and the degree of freedom $(\mathrm{df})=\mathrm{n}-1$ (29) where $\mathrm{n}=30$. The value of $\mathrm{T}$-test value will be higher than the $\mathrm{T}$ - table value $(6.696>2.045)$. There for can be concluded that now hypothesis (HO) is reject and the $(\mathrm{H} 1)$ is accept which means that there is significance different between the result of pre-test through chain whisper Technique in improving the students' listening ability.

\section{Analysis of data collect through the questionnaire}

To know the attitude toward the use of Chain Whisper Technique we can see the result of the questionnaire issued by the writer to respond. The questionnaire consist of 10 (ten) items. The analysis of those are presented below:

\section{(Item I)}

The students' opinion about English is difficult Lesson

\begin{tabular}{|c|l|c|c|}
\hline No. & Option & Frequency $(\mathrm{F})$ & Percentage $(\%)$ \\
\hline 1. & Strongly agree & 2 & 6.6 \\
\hline 2. & Agree & 19 & 63.4 \\
\hline 3. & Disagree & 9 & 30 \\
\hline 4. & Strongly disagree & - & - \\
\hline \multicolumn{2}{|c|}{ TOTAL } & 30 & $100 \%$ \\
\hline
\end{tabular}


Mukarrama dkk, Improving students' Listening Ability by Using Chain Whispering Words ...

Based on the table above, the researcher concludes that most of them agree or $19(63.4 \%)$ that English lesson is difficult for them.

(Item II)

The students' opinion about the difficulties part in English lesson is Listening

\begin{tabular}{|c|l|c|c|}
\multicolumn{5}{|c|}{ skill. } \\
\hline N0. & Option & Frequency $(\mathrm{F})$ & Percentage $(\%)$ \\
\hline 1. & Strongly agree & 4 & 13.3 \\
\hline 2. & Agree & 22 & 73.3 \\
\hline 3. & Disagree & 4 & 13.3 \\
\hline 4. & Strongly disagree & - & - \\
\hline & TOTAL & 30 & $100 \%$ \\
\hline
\end{tabular}

Based on the table above showed, the researcher got that most students agree $22(73.3 \%)$ that the difficulties part in English is Listening.

(Item III)

'The Students' Opinion about the Students' Difficulty in Understanding the Text of Listening test

\begin{tabular}{|c|l|c|c|}
\hline No. & Option & Frequency $(\mathrm{F})$ & Percentage $(\%)$ \\
\hline 1. & Strongly agree & 6 & $20 \%$ \\
\hline 2. & Agree & 20 & $66.6 \%$ \\
\hline 3. & Disagree & 4 & $13.4 \%$ \\
\hline 4. & Strongly disagree & - & - \\
\hline \multicolumn{2}{|c|}{ TOTAL } & 30 & $100 \%$ \\
\hline
\end{tabular}

Based on the table above, the researcher concludes that most of students agree or $20(66.6 \%)$ that they are difficult in understanding the text in Listening test. (Item IV)

The Students' Opinion about Listening Is Boring Lesson

\begin{tabular}{|c|l|c|c|}
\hline No. & Option & Frequency $(\mathrm{F})$ & Percentage $(\%)$ \\
\hline 1. & Strongly agree & 7 & $23.3 \%$ \\
\hline 2. & Agree & 15 & $50 \%$ \\
\hline 3. & Disagree & 8 & $26.7 \%$ \\
\hline 4. & Strongly disagree & - & - \\
\hline \multicolumn{2}{|c|}{ TOTAL } & 30 & $100 \%$ \\
\hline
\end{tabular}

Based on the table above, the researcher concludes that most of them 15 $(50 \%)$ of 30 students agree that listening is Boring lesson. 


\section{(Item V)}

The Students' Opinion about Effective Technique in Teaching Listening

\begin{tabular}{|c|l|c|c|}
\hline No. & \multicolumn{1}{|c|}{ Option } & Frequency $(\mathrm{F})$ & Percentage $(\%)$ \\
\hline 1. & Strongly agree & 12 & $40 \%$ \\
\hline 2. & Agree & 16 & $53.3 \%$ \\
\hline 3. & Disagree & 2 & $6.7 \%$ \\
\hline 4. & Strongly disagree & - & - \\
\hline \multicolumn{2}{|c|}{ TOTAL } & 30 & $100 \%$ \\
\hline
\end{tabular}

Based on the table above, the researcher got that just $2(6.7 \%)$ of 30 students disagree with the effective technique in teaching Listening. Most of them agree and strongly agree with that. It means that they need effective technique in Listening.

\section{(Item VI)}

The students' Interest in Studying Listening Through “Chain Whisper Technique"

\begin{tabular}{|c|l|c|c|}
\hline No. & \multicolumn{1}{|c|}{ Option } & Frequency (F) & Percentage (\%) \\
\hline 1. & Strongly agree & 9 & $30 \%$ \\
\hline 2. & Agree & 19 & $63.3 \%$ \\
\hline 3. & Disagree & 2 & $6.7 \%$ \\
\hline 4. & Strongly disagree & - & - \\
\hline \multicolumn{2}{|r|}{ TOTAL } & 30 & $100 \%$ \\
\hline
\end{tabular}

Based on the table above, the researcher concludes that most of the students were interested in studying listening if the teacher use "Chain Whisper Technique" in teaching.

\section{(Item VII)}

The students' Response about "Chain Whisper Technique" can make them easy to Understand the Listening Test.

\begin{tabular}{|c|l|c|c|}
\hline No. & \multicolumn{1}{|c|}{ Option } & Frequency (F) & Percentage $(\%)$ \\
\hline 1. & Strongly agree & 9 & $30 \%$ \\
\hline 2. & Agree & 21 & $70 \%$ \\
\hline 3. & Disagree & - & - \\
\hline 4. & Strongly disagree & - & - \\
\hline \multicolumn{2}{|c|}{ TOTAL } & 30 & $100 \%$ \\
\hline
\end{tabular}

Based on the table above, the researcher concludes that most of the students feel that they can understand the Listening test well by Using "Chain Whisper Technique". 
Mukarrama dkk, Improving students' Listening Ability by Using Chain Whispering Words ...

\section{(Item VIII)}

The Students' Enthusiasm in Studying Listening by Using “Chain Whisper Technique"

\begin{tabular}{|c|l|l|l|}
\hline No. & \multicolumn{1}{|c|}{ Option } & Frequency $(\mathrm{F})$ & Percentage $(\%)$ \\
\hline 1. & Strongly agree & 8 & $26.7 \%$ \\
\hline 2. & Agree & 20 & $66.6 \%$ \\
\hline 3. & Disagree & 2 & $6.7 \%$ \\
\hline 4. & Strongly disagree & - & - \\
\hline \multicolumn{2}{|c|}{ TOTAL } & 30 & $100 \%$ \\
\hline
\end{tabular}

Based on the table above, the researcher concludes that most of the students have enthusiasm in studying listening if use "Chain Whisper Technique" and they hope the teacher always use chain Whisper Technique Listening.

\section{(Item IX)}

Study listening with the Use of "Chain Whispering Technique" can increase Listening ability.

\begin{tabular}{|c|l|c|c|}
\hline No. & \multicolumn{1}{|c|}{ Option } & Frequency $(\mathrm{F})$ & Percentage $(\%)$ \\
\hline 1. & Strongly agree & 8 & $26.7 \%$ \\
\hline 2. & Agree & 22 & $73.3 \%$ \\
\hline 3. & Disagree & - & - \\
\hline 4. & Strongly disagree & - & - \\
\hline \multicolumn{2}{|c|}{ TOTAL } & 30 & $100 \%$ \\
\hline
\end{tabular}

Based on the table above, the researcher concludes that the use of "Chain Whisper Technique" can increase Listening Ability.

\section{(Item X)}

Study Listening with Use "Chain Whisper Technique is not boring.

\begin{tabular}{|c|l|c|c|}
\hline No. & \multicolumn{1}{|c|}{ Option } & Frequency $(\mathrm{F})$ & Percentage $(\%)$ \\
\hline 1. & Strongly agree & 5 & $16.7 \%$ \\
\hline 2. & Agree & 20 & $66.6 \%$ \\
\hline 3. & Disagree & 5 & $16.7 \%$ \\
\hline 4. & Strongly disagree & - & - \\
\hline \multicolumn{2}{|c|}{ TOTAL } & 30 & $100 \%$ \\
\hline
\end{tabular}

Based on the table above, the researcher concludes that "Chain Whisper Technique can create the Students a fun learning situation, and most of them agree or $20(66.6 \%)$ about that. 


\section{E. DISCUSSION}

The discussion of data analysis of pre-test and post-test in experimental class aims to answer the question as follows: is chain whispering sentence technique in improving students' listening ability at SMP Somba Opu Sungguminasa Gowa. It was supported by

Faridah, Kartono, Siti Halidjah(2012)"The Use Chain Whisper technique to Improve Ability Listening skill. On observation listening skills using game chain whisper technique was successful. It is evident from the increase listening skill which has increased from the first cycle to the meeting 1 and 2 and cycle 2 meeting 1 and 2 .

Apriani Sufiarti,A.A.I.N. Marhaeni, I.M. Sutama (2013) "The influence using chain whisper technique on listening skills and learning interests of students". Results of the research show that English listening skills and learning interests of students who take lessons using chain whisper technique is higher than the group of students who take conventional learning. These results also demonstrate that using chain whisper techniques in learning English can improve listening skill and students' interest in learning English

.Kurnia Zulianti PBI FKIP Unisma (2013)"Improving Speaking Achievement using chain whisper game". The result of the researcher data analysis, using chain whispering Technique can increase the students' listening ability. It is supported by mean score of the result of the students' pre- test and post- test or before and after treatments was given to students.

The means score of the students pre-test was 6.56 and the mean score of the students' post- test was 7.23. The mean score of post -test was higher than the means score of pre-test. It means that Using Chain Whisper Technique can increase the students' ability.

There were was a significance of listening test before and after using Chain Whisper Technique, the result of analysis, through questionnaire (attitude scale) shows that positive attitude toward the using Chain Whisper Technique in Teaching Listening.

Based on the discussion above, it can be concluded that the first year students of SMP Somba Opu Sungguminasa Gowa, using Chain Whisper Technique can increase the students listening ability. While the result of the questionnaire shows that a positive attitude and can increase the students' interest in teaching listening by using Chain Whisper Technique. In order words, there are the importance of chain whisper technique as follow: To improve the students ability in listening skill, to measure the students ability in listening skill, this technique is easy to apply. (Ice Sutari, Tiem Kartini, Vismaia, 1997:143-144) 
Mukarrama dkk, Improving students' Listening Ability by Using Chain Whispering Words ...

\section{F. CONCLUSION}

Based on the result of the data analysis in the previous finding and discussions, the researcher puts some conclusion as follows:

1. Chain Whispering Technique can be used to improve the students' listening ability at the first year students of SMP Somba Opu Sungguminasa Gowa.

2. Chain Whispering technique can increase the students listening ability. It is proven by the mean score of post-test (7.23) was higher than the means score of pre-test (6.56).

3. Chain Whispering Technique can increase the students' interesting in teaching listening. It is proven by the data of the questionnaire shows that the students gave positive attitude toward the use Chain Whisper Technique in teaching listening.

\section{G. SUGGESTION}

Based on the result of data and conclusions, the researcher suggest: It is suggested to the English teacher especially those who teach the listening, using Chain Whispering Technique because it is can increase the students listening ability. English teacher should be more creative and innovative in selecting teaching materials especially in listening class. It is suggested to do English teacher, make listening lesson are interesting material and activate pre-listening activity.

\section{REFERENCE}

Arikunto, Suhartini. 2002. Prosedur penelitian: Suatu Pendekatan Praktek. Jakarta: PT. Rineka Cipta.

Arsyad, Azhar. 2003, Step by Step Reading in English For IAN Student, Yogyakarta: Pustaka Belajar.

Faridah, kartono, siti halidjah.2012. The Using Chain Whisper Technique to Improve Ability Listening Skill. E-mail. Faridabfaridab760@gmail.com. Retrieved on july 11:30 pm.

Gay, L.R. 1981. Educational Research. Columbus: Memill Publishing company.

Goh, C. C. 2002. Teaching listening in the language classroom. Singapore: SEAMEO Regional Language Centre.

Grenee, Harry A. et. al. (1969). Developing Language Skils in The Elementary Schools. Boston: Allyn and Bacon, Inc.

Ginther, A. (2002). Context and content Visual and Performance on Listening Comprehension Stimuli. Language Testing. 
Helgessen, M. 2004. Listening in practical English language teaching. In Nunan, D. (Eds.) Beijing: Higher Education.

Kline, John. A. 1996. Listening Effectively. Air University Press.

Longman, A. W. 1998. Dictionary of English Language and Culture. $2^{\text {nd }}$ ed. London : Academic Press Inc.

Logan, Lilian M. et.al. (1972). Creative Communication: Teaching the Language Arts. Toronto: Mc Graw-Hill Ryerson Ltd.

Morris, Anton C.et. al. (1969). Multimedia System Design. New York: Harcount Boace \& Word, Inc.

Meskill, C. (1996). Listening Skills Developing Language Through Multimedia. Jurnal of Educational Multimedia and Hypermedia. (1996) 5 (2), 179-201. Department of Educational Theory and Practice, University at Albany, State University of New York, Albany USA.

Oura, Gail. K. 2012. Authentic Task - Based Material: Bringing the Real World into the Classroom (online) bttp:// www.jrc.sophia.ac.jp/kiyou/ki21/gaio.pdf. Retrieved February 20, At 1:27 pm.

Ockey, G.J. (2007). Constuct Implikations of Including Skill Image or Video in Computer Based Listening Test. Language Testing.

Porter, D. \& Roberts, J. 1981. Authentic listening activities. ELT Journal, 36 (1).

Rost, Michael. 1991. Listening in action (english language teaching). New York: Prentice hall, ELD.

Rost, Michael. 1994. Intoduction listening. London; penguin .

Siberman Mel. 2009. Active Learning: 101 strategi pembelajaran aktif, (Cet. V1). Yogyakarta: Pustaka Insan Madani.

Suhartini. 1993. The listening ability of the third semester of the English education Departament of FPBS IKIP Ujung pandang. Makassar. Thesis FPBS IKIP Ujung pandang.

Sutari, I. et.al. (1997). Menyimak. Jakarta: Depdikbud.

Sufiarti apriani. 2013. The Influence Using Chain Whisper Technique on Listening Skill and Learning Interests of Student. E-mail._Apriani.Sufiarti@pasca.Undiksha.Ac.id. Retrieved on juny 02, 1:15 pm.

Steven. A. Beebe, Susan J. Beebe (1992). Public speaking. International Edition. Pearson.

Thesis. 2012. The Use of Text Based Task to Improve Students Listening Ability. bttp:/ / www.skripsi-ptk-use-of-text-based-task-to.btml. Retrieved on February 2, At 12:51 pm. 
Mukarrama dkk, Improving students' Listening Ability by Using Chain Whispering Words ...

Tarigan, D. (1986). Keterampilan Menyimak Modul 4-6. Jakarta: Karunika.

Tarigan, H. G. (1990). Menyinak Sebagai suatu Keterampilan Berbahasa. Bandung: Angkasa.

Underwood, Mary. 1989. Teaching Listening. New York: Longman.

Walter, O. W, and Schoot, R. L. 1979. Thinking and speaking. The fourt edition. New York: Mac Millan publishing CO.INC 